\title{
Conceptualising the Australian telecommunications industry self-regulation scheme in the context of Australian judicial system and administrative justice
}

\author{
Grace Li
}

Faculty of Law, University of Technology Sydney

\begin{abstract}
The public ombudsman plays an irreplaceable role as an important redress mechanism for individual grievances and as a "watch dog" to administrative justice.

Since the 1980s, private sector ombudsmen have emerged and proliferated. This rapid development has resulted in some significant controversies. Unfortunately, many of these controversies have not been sufficiently addressed to date. By analysing the Telecommunications Industry Ombudsman (TIO) as a case study, this article seeks to examine the nature of the private sector ombudsmen and its changing position in relation to administrative justice. Here, the key claim is that the TIO is substituting courts with respect to consumer matters arising from its service sector. Stemming from this claim, this article further argues that the current TIO scheme presents an inappropriate and unreliable situation where the private sector ombudsmen may provide differing rights and remedies from those available in the Courts. Furthermore, consistency in decision-making by private sector ombudsmen can be problematic, and fair procedure requirements remain untested by the courts. In order to resolve these issues, private sector ombudsmen, like the TIO, should be subject to a closer monitoring process. As a preliminary measure, an authoritative and standardised quality control assurance mechanism should be established to ensure that consumer complaints are effectively received and fairly handled.
\end{abstract}

Keywords: Telecommunications industry ombudsman, the TIO, public ombudsman, industry consumer dispute resolution.

\section{Introduction}

An ombudsman, as a distinctive method of alternative dispute resolution, has been widely adopted in the public sector of many countries (Commonwealth Ombudsman 2015a). The original function of the public ombudsman was to provide a redress to the grievance of citizens. However, over the years this role has been expanded to provide a forum for settling disputes by allocating a financial reward to the winning party. In the 1980 s this shift became 
particularly prevalent with the development of industry self-regulation schemes in the private sector, signifying the beginning of the growth of private sector ombudsmen.

The tangible transplantation of industry-specific private sector ombudsmen initially commenced in key industries that were privatised from former state-owned businesses, such as banking, insurance and utilities. An illustrative example of the application of the public ombudsman into the private sphere is the world's first private sector ombudsman, the Insurance Ombudsman Bureau (IOB) in the United Kingdom, established in 1981. Birds and Graham (1988) while stressing the paucity of evidence, have argued that the IOB was founded on the intention of the owners of IOB to deter statutory intervention. Despite attracting criticism, the IOB became the inspiration and a model for a variety of private ombudsmen schemes worldwide (Tyldesley 2003).

The adoption of ombudsmen schemes has become pervasive in the private sector, but not without controversy. Johnson describes private sector ombudsmen as a cynical exercise, where ombudsmen become a substitute for structural reform in the operation of industry (Gill 2014). Similarly, Morris (1987) asserts, 'ombudsmen are destined to become permanent features in the private sector and indeed, at least in crude quantitative term, could eventually supplant the legal process as the primary form for the formal and informal resolution of disputes between business enterprise and consumers...'

Notwithstanding prolonged focus on the fundamental issues that these controversies expose, including the legal standing of the private ombudsmen in the judicial system and concerns over fair procedure, many of these issues remain unsettled after more than thirty years since the establishment of the IOB. Indeed, the principal aim of this paper is to contribute to the relatively under-represented body of research produced by Australian academics in the area of ombudsmen practice. Furthermore, this paper argues that the development of ombudsmen practice is progressive, in which the impact of earlier schemes was limited by the voluntary basis of their adoption.

The current landscape has changed considerably from the early days. Private sector ombudsmen have been established in almost all key service sectors throughout the world, including in Australia. Nowadays, there is a large number of private sector ombudsmen acting as statutory-based compulsory schemes - mandating firms to participate. Through the ubiquity of private sector ombudsmen schemes consumers have become better-informed about the number of services provided by the ombudsman.

Private sector ombudsmen schemes have been applied in different forms across various industries, resulting in multiple, differing processes for complaint handling. Therefore, it is beyond the scope of this paper to identify ' $a$ ' particular preferred institutional model of the 
private ombudsman. Rather, this paper uses the Australian Telecommunication Industry Ombudsman (TIO) as a case study in order to reflect the broader issues and possibilities produced by the application of ombudsmen schemes into the private sector. This methodology not only provides a manageable scale of research but also presents an opportunity to provide direct benefits to the scheme studied.

The Australian telecommunications industry exemplifies both the proliferation of statutorybased compulsory ombudsmen schemes in the private sector and the reasonably high level of consumer engagement with the schemes. In 2015, the number of mobile services operating in Australia was 31.77 million (Australian Communications and Media Authority 2015) while the total population in the same year was approximately 23 million (Australian Bureau of Statistics 2015). These figures indicate that the entire Australian population are telecommunication consumers, with many operating more than one device and purchasing services from more than one provider. These statistics reflect the significance of having an effective redress scheme in this service sector. Additionally, these figures demonstrate the critical impact that a redress scheme can have on people's daily lives. Beyond the telecommunications industry, many other sectors can have a substantial impact on consumers and firms, such as in banking and utilities. It is therefore vital to have well considered industry schemes that are capable of delivering fair outcomes.

In summary, the research inquiry present in this paper is to study whether private sector ombudsmen, like the TIO, perform a similar role as the traditional public ombudsmen. If not, the objective is to understand what the legal standing of the private sector ombudsman is in the judicial system and the administrative structure. In order to do so, Part One of this paper provides context for later discussion as a background to the rise of private sector ombudsmen so as to situate the Australian experience within global trends. Part Two examines the processes and practices of the TIO in detail, while Part Three establishes the key claim that the TIO is operating as a substitute to the judicial system on consumer matters arising from this service sector. Stemming from this key claim, Part Four explores five related aspects of the TIO's decision making process, including the TIO's power to expand its jurisdiction; consistency of decision making; procedure fairness within an informal forum; and problems with using the term 'ombudsman' as its name. Finally, Part Five concludes by summarising the findings from previous sections and making suggestions for moving forward.

\section{Context}

The intensification of industry self-regulation has presented many different regulatory forms ranging from a single industry code of practice to more sophisticated dispute resolution 
schemes, such as an industry specific ombudsman scheme (Gunningham \& Rees 1997). In the 1980 s, the trend of industry self-regulation occurred within a context whereby 'the corporation' was increasingly becoming and being understood as an object of protection in Western capitalist societies. The past thirty years have witnessed a surge in self-regulatory regimes in the United States, Europe, and other advanced economies including Australia (Kagan 1982). In particular, industry self-regulation grew out of the understanding that firms will voluntarily make agreements that lead to the 'socially optimal resource allocation and output mix' in order to avoid negative impacts on consumers and society, and to improve their marginal costs (Coase 1960: p.96). Indeed, whenever problems of "negative externalities' such as pollution or systemic risk in unregulated finance, are perceived to be not just limited to the practices of a single firm but rather endemic to an industry, concerted action is necessary. Many industries today engage in various acts of self-regulation, with which they claim to contribute to the mitigation of the respective problems that their industry creates (Flohr et al 2010). Few industries remain disengaged in organising around a formally established framework that sets self-prescribed standards for ethical conduct within their industry (Sammeck 2012).

The shift in regulatory bodies from a public ombudsman to industry specific self-regulation schemes developed alongside the privatisation of publicly- owned services. At the time of widespread privatisation, a common feature involved an independent ombudsman acting as a referee or a sort of backstop when internal complaints procedures in private industry firms failed. Many of these early schemes were purely voluntary, while others had a statutory basis. The schemes were usually free and decisions were binding on the firm rather than the consumer. Broadly, the ombudsman scheme is characterised by a tiered approach with an initial assessment stage to determine the eligibility of the complaints. If a complaint meets the eligibility criteria it is forwarded to the conciliation process and then to the final determination stage.

\section{The TIO}

The TIO was established in 1993 when competition was first introduced to the telecommunications industry in Australia. The TIO was recognised under the Telecommunications Act 1991 (Cth) which mandated the creation of an organisation to handle telecommunication services related complaints, and that such an organisation should be independent of the industry, the government and customer organisations. The TIO scheme is exclusively funded by industry and its services are provided free of charge for consumers (TIO 2015e). 
The TIO's complaint process starts with consumers filing complaints with the TIO after their attempts to solve the matter directly with the individual service provider fail. To enliven the TIO's jurisdiction a complaint must be about a matter less than two years old (six years old in some cases) (TIO 2014b). Furthermore, the extent of the TIO's authority to resolve complaints is up to the value of $\$ 50$, oooo. These resolutions are binding on the providers if accepted by the complainant. Additionally, the TIO can also make recommendations to the complainant's telecommunications provider up to the value of $\$ 100,000$, although the provider is not obliged to accept the recommendation. (TIO 2015i). In dealing with complaints, the TIO primarily gives regard to relevant laws, good practice, and what are fair and reasonable working principles (TIO 2015d). Additionally, the TIO considers industry dispute benchmarks as a factor in finalising decisions (TIO 2015a).

As a primary forum of individual telecommunications consumer dispute resolution, the TIO has received a large numbers of complaints over the years (TIO 2015c). Between 2014 and 2015, the TIO received 124,417 complaints (TIO 2015j). The TIO assists providers and the industry more broadly in the improvement of the provision telecommunication services by identifying, investigating and monitoring systemic issues in the sector, in order to make recommendations to the service providers (TIO 2015a).

The TIO operates independently with no formal relationship to the industry, consumers, regulators, the judiciary or the administration. The TIO's decisions may be appealed on points of law to the court. The decisions of the ombudsman are based on a number of factors, including relevant laws, the terms of the contract and industry codes, as well as what is fair and reasonable in all the circumstances of the case (TIO 2015f). Thus the TIO has greater flexibility and discretion to apply fair rulings that are not necessarily based on precedent than that of the court. The complainants are able to register complaints via the phone or the internet and have their claims processed without the oftentimes laborious or time consuming paperwork and the risk of costly representation fees involved in attending court. In other words, by operating outside the court system, the TIO is able to approach dispute resolution in a way that abates some of the criticisms often leveled at the court and of the judges.

The TIO process of deciding on a complaint encompasses many distinctive features that differ from the court system. For instance, in the process of making decisions, the TIO are able to consult with the disputing parties and all other relevant persons, which is indicative of an 'inquisitorial power' absent from Australian judges. The TIO is not obligated to follow "the established laws", rather the TIO makes its own decisions and enacts changes at any given time as it is not bound by the "precedent". The TIO may resolve disputes by making decisions based on only written evidence and/or verbal conversations over the phone. No 
physical presence at a hearing is required and the TIO freely decides on whether the evidence is admissible.

The TIO can also pre-empt certain situations based on industry data and best practices, while courts normally refuse to consider hypothetical cases. That is, the TIO may choose to actively intervene to reduce or prevent disputes from arising by identifying systemic issues and communicating these issues with the industry and consumers. For example, in 2011, telecommunications provider Aero Telecom was found by TIO to be misrepresenting its service to consumers and consumers were inadvertently switching providers without realising this until receiving their first bill. TIO contacted Aero Telecom and requested that they modify their company practice to ensure they are receiving informed consent; as a result Aero's sales scripts were amended accordingly and staff were provided with a quality assurance program (TIO 2012).

Additionally, the TIO is able to look consciously at and therefore prioritise public interest considerations, rather than leaving this task to policy makers or established law. TIO works closely with the industry regulator on the consumer-related policy agenda and development. Free consumer access to the TIO encourages service providers to act more effectively in accordance with the industry code than the court system, where consumer access may only become possible with according to a certain level of cost and time.

The TIO provides an effective model in providing a party with a meritorious, substantive complaint redress, including compensation, within a short timeframe. Despite the efficiency of the TIO, the question remains whether a private sector ombudsman, such as the TIO, has legal standing in the judicial system and the administrative structure. To seek the answer the following part examines two parallel relationships: the relationship between the TIO and the court; and the relationship between the public ombudsman and the court. This comparative analysis aims to test the key claim of this paper, that private sector ombudsmen are substituting the judicial system in regards to consumer matters and assess what impact this change has on the consumer, the provider and the industry.

\section{Is the TIO is fundamentally different from the public ombudsman?}

To examine the relationships between public ombudsmen, the TIO, the courts and the administration, an important jurisprudence concern must be considered. That is that public sector ombudsmen are not regarded as alternatives to the courts, which sets a critical theoretical position for the assessment of private sector ombudsmen such as the TIO. 


\section{Public Ombudsman vs. the Court}

A widely accepted feature of the public ombudsman is that public ombudsmen do not function as substitutes to the courts, but rather as act as part of the administrative process (Nobles 2001; Bames 1993). This important foundation amplifies the legality of the public ombudsman. This paper outlines four key reasons to support this argument.

Firstly, matters dealt with by the public ombudsman are different from matters dealt with by the court. Public ombudsmen largely deal with complaints against bodies that are directly or indirectly subject to democratic accountability. For instance, in Australia, the Commonwealth Ombudsman investigates complaints about the actions and decisions of Australian Government departments and agencies. These investigations can include complaints registered against the quality of service delivered by private contractors hired by the Australian Federal government or the provision of oversight of complaint investigations by the Australian Federal Police. In addition, The Ombudsman can also investigate complaints about delays in processing Freedom of Information requests (FOI) and complaints about FOI charges (Commonwealth Ombudsman 2015b). The States and Territories in Australia also have their own Ombudsman offices with similar jurisdiction as the Commonwealth Ombudsman, except over State and Territory government authorities. All these matters are beyond the scope of the Australian courts.

Secondly, the role of the ombudsman is different from the role of the judge. A public ombudsman is an official, usually (but not always) appointed by the government or Parliament, who is charged with representing the interests of the public by investigating and addressing complaints reported by individual citizens (Commonwealth Ombudsman 2015a). This form of representation is derived from the widely understood imbalance of power between the agencies of government and those in which it governs. In practical terms the role of the public ombudsman is to provide redress for individual grievances and improve the standards of administration (Seneviratne 2002). However, the role of the judge is to act within their capacity as a public official to preside over matters of the law and administer justice.

In theoretical terms, Abraham argues that the public ombudsman "humanises the state administration" (Abraham 2008), by "supervising the administrative activities of the executive" (Reif 2004). While others have suggested that the public ombudsman also enhances government accountability to the public (Paunio 2009), strengthens the bond of trust between the citizen and the state (Kirkham, Thompson \& Buck 2009) and provides a safety net for when public administrations underperform or overreach. Ultimately, as Gilling 
states, "ombudsmen represent the possibility for ordinary people to bring to account the leviathan of the modern state" (Gilling 1998).

The concept of the ombudsman as an independent person who is able to investigate and resolve disputes between citizens and the agencies of the government has spread to over 120 countries and is seen to be an essential accountability mechanism in democratic societies. The role of the public ombudsman in redefining the constitutional relationship between public services and the public is as important as ever, given the growing reach of government into every aspect of citizens' lives.

Thirdly, citizens' perception of using public ombudsmen is different from their perception of using the courts. In general, a citizen may register a complaint with a public ombudsman about a particular grievance that may not be necessarily based on legal factors. For example, one can file a complaint with the Postal Industry Ombudsman as a branch of the Commonwealth Ombudsman (as Australia Post is a government-owned agency) about the loss, redirection or damage of post. Many of these forms of complaints are in nature not directly related to the decisions of the public administration. The ombudsman may be able to make recommendations about these types of issues (Australian Administrative Law Policy Guide 2015); however, these types of issues are difficult to present to the courts as "legal issues". A party who seeks the aid of an ombudsman does so with an expectation of quick, inexpensive, and confidential counselling as to how to navigate the bureaucracy and red tape facing the party. The ombudsman may intervene for a party who has been frustrated by the system so that the party's needs might be addressed.

Moreover, the legal effect of the public ombudsman's decision is different from the decision of the court. The majority of public ombudsmen make non-binding recommendations rather than legally binding decisions, this is due to the fact that citizens who complain to the public ombudsmen rarely do so because they are seeking to enforce legal rights. Rather, the substance of complaints received by public ombudsmen are typically about the quality, delivery and function of a particular government service as opposed to criminal or civil mistreatment. This seems to be a natural consequence of the development of the public ombudsman as an institution, from the first public ombudsman, the Parliamentary Commissioner for Administration in the United Kingdom, which was regarded as a means of supplementing the work undertaken by Members of Parliament on behalf of aggrieved constituents (Wyatt 1961). Although some citizens' complaints may duplicate matters, which could be the subject of applications for judicial review, they do not usually involve matters that may be the subject of actions in contract (Seneviratne 1994). 


\section{TIO vs. the Court}

The use of the term "ombudsman" for both private sector and public ombudsmen creates the impression that they perform similar roles. However, as the following part will illustrate in keeping with the example of the TIO, the public and private sector ombudsmen perform rather different roles and function.

Firstly, matters dealt with by the TIO are similar to the matters dealt with by the court. The nature of complaints filed varies based on the particular industry. In the case of the TIO the complaints are overwhelmingly concerned with billing, service provision, and service contracts (TIO 2015g). These matters are private matters between the complainants and the industry members and are well within the jurisdiction of the traditional courts. That is, the complaints filed with the public ombudsman differ greatly from the complaints registered with the TIO.

Secondly, the role of the private sector ombudsman is similar to the role of the judges. The TIO has significant decision-making powers with the ability to decide on resolutions of up to the value of $\$ 50,000$ and recommendations of up to the value of $\$ 100,000$ (TIO 2015i). The fiscal value of the TIO's resolution is substantially more than the jurisdictional limit of the local court in its Small Claims Division $(\$ 10,000)$, and the fiscal value of the TIO's recommendation matches with the jurisdictional limit of the local court in its General Division $(\$ 100,000)$ (NSW Local Court Act 2007). Comparatively, the public ombudsman does not usually have the power to grant fiscal awards this large.

Thirdly, the consumers' perception of using private sector ombudsmen is similar to the perception of using the courts. Complainants using TIO's services seek to have disputed matters redressed and/or financially compensated. Accordingly, the perceptions of the TIO's outcomes are more linked to financial award than the outcome of a matters addressed by the public ombudsman, which is more likely to result in a higher quality service or the resolution of the particular matter at hand. In fact, TIO's 2015 annual report reveals that almost 65 per cent of its recorded outcomes had either only a financial outcome or both a financial and non-financial outcome (TIO 2015c).

Fourthly, the legal effect of the private ombudsman's decision is different from but comparable to the decision of the court, particularly in that the TIO's resolutions are binding to participating service providers if accepted by the complainants.

These four distinct comparisons demonstrate key differences between the public ombudsman and private sector ombudsmen in the judicial system. It also recognises a particular resemblance between the private sector ombudsmen and the Courts. That is, both 
the TIO and the Court have the jurisdiction to hear the cases of the type normally presented to the TIO in the form of a complaint The TIO and the court have powers to grant fiscal awards to the winning parties in the dispute. Consumers access the TIO's service to get the matter redressed or compensated and the TIO's decisions are binding to participating firms once accepted by the complainants. Therefore, the function of the TIO has evidently deviated from the traditional public ombudsman service.

Nobles summarises the way in which the previous comparisons have highlighted the expansion of the TIO into the role of substituting the Court, "private sector ombudsmen offer an alternative to the pursuit of remedies through existing courts and tribunals. The use of ombudsmen is no longer limited to the provision of non-legal remedies, that is to grievances for which there is no (or hardly ever) a remedy at law, but the provision of alternative remedies to those available at law' (Nobles 2001). By the same token, Morris and James also argue that: "the second generation of ombudsman (private sector ombudsman) provided a genuine alternative to the courts dealing with cases which the complainant might otherwise have taken to court." (Morris \& James 2002). Thus, a key claim of this paper can be justified at this point - as a private sector ombudsman, the TIO performs a fundamentally different role to the traditional public ombudsman, and is in fact substituting the judicial system for consumer matters arising from its service sector.

\section{Five Critical Features Represented in the TIO Model}

If the TIO is established as an alternative to the court, as evidence suggests above, several fundamental issues arise in regards to this expansion of the TIO. These issues include but are not exclusive to the following five examined aspects of the TIO's operation as an alternative to the Court.

\section{To what extent can the TIO provide different rights and remedies from those that may be available in courts?}

When comparing private sector ombudsmen to the Courts, one must consider the role played by the Courts in modifying apparently settled rules of law or specific legal arrangements in accordance with general ideas of justice, fairness and reasonableness. This includes techniques ranging from developing the common law to adopting liberal or restrictive styles of interpretation. As Nobles points out: “... the question here is thus not whether ideas of fairness may or may not restrict or extend the apparent scope of legal duties, but whether this may or may not be done by someone who is not a judge (Nobles 2001).

Relating this point to the TIO in the context of the established key claim above, one might wonder who are the people that make real decisions in the TIO? Indeed, are they legally 
trained or do they need to be legally trained? These questions, on face value appear simple to answer; however locating answers has been rather difficult.

Firstly, who are the decision-makers in the TIO? For an organisation the size of the TIO, there is surely a complex internal structure in place to resolve the large number of complaints received. The ombudsman would not be the only person to decide on the matters presented. The number of people deciding matters at the TIO is not publicly available. However, the TIO's 2015 annual report indicated that the TIO had a total of 191 employees at that time and the majority of its staff engages in dispute resolution (TIO 2015g). Therefore, the decision making process, unlike in the Court system, is decentralised among many people who may differ in their experience and in their subjective interpretation of what is reasonable and fair in individual cases.

Follow on questions may include - are these decision-makers legally trained? Indeed, should they be legally trained? The answers to these questions are unclear from the TIO's website. Nonetheless, reading the position description of an 'enquiry officer' on TIO's career website indicates that the position does not require possible candidates to have any legal background. Rather, candidates must rather demonstrate experience in customer service, additionally knowledge of the telecommunications industry is desirable. (TIO 2015b). Thus, the TIO's employment policy expresses the view that the 'idea of fairness' raised by Nobles does not need to be administered solely by a judge in the area of telecommunications, but can be delivered by those who have experience in dealing with customer complaints (Nobles 2001).

A previous study on the TIO scheme conducted by Widdowson and Li collected a series of TIO's decisions by inviting submissions (decided cases) from the TIO's members. The findings from examining the TIO's decisions, in that particular project revealed that remedies decided by the TIO could be very different from the possible considerations from a legal point of view (Widdowson \& Li 2013).

Therefore, what is at stake here goes beyond the accessibility and convenience of utilising the TIO as opposed to Court. Rather as it is suggested here, the TIO may be providing different rights and remedies than those available in courts and tribunals, which as a matter of structural principle, should be the subject of profound exploration and monitoring.

\section{Why can the TIO freely expand its own powers?}

Important consideration must also be given to the TIO's capacity to expand its own powers. Currently, the TIO is able to expand its powers at its own discretion. A recent example of this expansion of powers is in regards to the limit of time that a customer has in order to make an 
eligible complaint. TIO extended the time frame significantly, allowing customers to raise complaints about certain circumstances that occurred two years ago (up from the previous limit of one year). This change in TIO policy resulted in an extra 359 consumer complaints than would not have been possible in the previous year (TIO 2014a). The expanded powers followed a series of reviews of the TIO's complaint handling policy, which also included an increased value of fiscal amounts possible for dispute and the adoption of a more flexible approach for defining a small business (TIO 2014a).

Whether or not these power expansions are beneficial is a different issue, but the fact that a private institution, substituting the judicial system, is able to expand its powers at its own discretion certainly creates some real concerns. An important question can be asked on this point - should the current system allow a private dispute settlement scheme with significant powers to further expand its powers and jurisdiction; and if so, what would be the social, economic and constitutional rationale for it? This question becomes more critical when considering that the TIO is the only consumer scheme available in this service sector and that it is compulsory for the service providers to participate. Thus, expanding the jurisdiction of the TIO to further potential complaints might add an unnecessary financial burden to the service sector as a whole.

\section{How can the consistency of decisions made by the TIO and the quality of the TIO's decision-making be maintained?}

The power to "do justice in an individual case" has become something of a hallmark of private sector ombudsmen as they do not follow the doctrine of precedent and therefore are able to take considerations of substantive fairness into account in their decision-making. This is an important power in the service sectors, where there is often inequality of bargaining power between the service provider and the consumer. The TIO has made clear that it is "not bound by previous decisions, and considers each enquiry or complaint on its individual merits" (TIO 2015d). In general, the overriding criterion to be used in dispute resolution is for the ombudsman to do "what is, in his opinion, fair and reasonable in all the circumstances of the case" (TIO 2015d).

This, however, is not an uncontroversial power (Morris \& Hamilton 1996). When forming a view, assessing any evidence, or making a decision, the ombudsman must also take into account "the relevant law, regulations and good practice". The advantages of this type of equitable jurisdiction, however, must be set against the opposing value of legal certainty and associated rule of law considerations (Nobles 2001). This has been recognised in the past by ombudsmen who have stated that they sought to achieve consistency of decision-making 
while retaining the ability to depart from usual practice where deemed appropriate (Smith \& Wood 2009).

It may be easier to ensure consistency when decisions about similar products are being made within the same institution, but the sheer size of the institution will also have an impact on the mode of decision-making. The fact that the TIO dealt with 138,946 new complaints in a single calendar year (TIO 2014a) makes it fair to assume that this is an institution where a number of subsidiary ombudsmen (or case officers) are required to make consistent decisions within a highly formalised managerial structure, and where the ombudsman fulfills a function more akin to that of a corporate style Chief Executive Officer than a quasi-judicial decision-maker. In the interests of ensuring that similar cases are treated alike, private sector ombudsman institutions like the TIO should have in place internal procedures including regular meetings and training, and moderation or crosscheck processes to make sure that decision-making principles are well understood and appropriately applied by all decisionmakers. Whether or not these policies have been adopted by the TIO is not published on their institutional documents or media accounts and thus examining and evaluating on the TIO's practice in this aspect is not feasible.

On the other hand, there is often a fine balance to be struck between the rational application of rules to ensure consistency and an over-reliance on rules, which may lead to a failure to exercise discretion in individual cases (Hilson 2002). If the TIO were to lean too far towards a strict rules-based approach because of the size of its operation and delegation arrangements, it may pave the way for challenges on the ground against a fettering of discretion through the rigid application of decision-making principles or rules. Thus, the challenge for private sector ombudsmen, like the TIO, is defined by the extent in which they are able to balance their discretionary power being exercised by delegated decision-makers, and to ensure that general decision-making principles are appropriately applied across the entire institution.

This challenge is endemic to the functioning of private sector ombudsmen (Morris \& James 2002). Merricks has proposed the development of particular benchmarks to measure the accuracy and consistency of decision-making in individual cases and to identify instances where individual discretion was exercised (Merricks 2001). Unfortunately, 15 years have since passed and Merricks' proposition has not become standard industry practice and many industry ombudsmen, including the TIO, are yet to adopt benchmarking.

The other relevant matter here that speaks to the capacity of private industry ombudsmen to administer fairness and reasonableness is the maintenance of quality in decision-making. In order to make a full assessment of the quality of the TIO's decision-making process, the 
reasons and details of the particular cases processed by the TIO are necessary. However, these records are unavailable to the public and there has been little interest or scrutiny from academics, in particular legal scholars, to increase the accountability of their processes. Additionally, despite being a scheme pre-empting review by a Court there has not been a considerable amount of legal scrutiny of the TIO, nor is there a standing mechanism upon which the private sector ombudsmen schemes are regularly reviewed. The lack of accountability, scholarly inquiry and judicial scrutiny has resulted in a process that is remote from consumers that emphasises the process over the substance of decision making. As the TIO is a cheaper and quicker option, there is a risk of creating a two-tier system of justice delivery or an institutional bias whereby the literate and technology savvy class are more able to navigate the Courts or dispute decisions made by the TIO, while the elderly, the working class or the disabled are given fewer options. Although it might be cheaper to avoid hearings, the question remains whether denying consumers a 'day in court' may eventually erode public confidence in the private sector ombudsmen schemes. At present, however, the consumer has nowhere else to go.

The TIO has put in place programs to train and educate staff to improve the services they are able to provide and their decision making processes. For example, TIO's 2014-15 annual report, launched in 2014 includes an educational program, which awards a Graduate Certificate in Dispute Resolution together with the Box Hill Institute in Victoria. This program focuses on developing the dispute resolution, case management, communication and legal skills of dispute resolution officers and aims to improve the quality of the TIO's services in the long term (TIO 2015g). Programs like this may not fundamentally resolve the issues of quality or consistency of decisions or decision-making processes. However, increasing the skills of dispute resolution officers will bring some benefits to the TIO and its member firms, as well as to telecommunications consumers at large. To further improve the TIO's service and so to gain public confidence and industry support, developing a particular sectorial staff training program is essential. It is a good way to start but there is a lot more that needs to be done in this regard.

\section{How is it possible to improve procedural fairness within informal dispute resolution schemes like the TIO?}

As one would expect, the rules on complaint handling are heavily influenced by requirements of procedural fairness by the ombudsman office. For example, in the TIO, if the ombudsman decides that an investigation is necessary, the ombudsman provides both parties with an opportunity to make representations during the investigation stage, and sends a provisional assessment to both parties giving them a time limit within which to respond. If either party 
indicates disagreement with the provisional assessment the matter then proceeds to determination (TIO 2015d). There is considerable autonomy on the part of the ombudsman to decide the evidence required, whether it should be written or oral, and how it should be presented. The ombudsman may exclude evidence which would be admissible in court, or conversely include evidence that would be inadmissible. The private sector ombudsman may accept information in confidence so that a summary or edited version only is submitted to the other party; the ombudsman may also take into account the failure of either party to provide information and make a decision on that basis, and may dismiss a complaint if a complainant fails to supply required information (Morris \& James 2002).

These procedures are designed to fit a largely paper-based inquisitorial investigative method of operation, which is the norm within the TIO. How the courts might view this approach if judicial review challenges the issues of fair procedure and the extent to which the fair procedure requirements will impinge on the established processes of the ombudsman remains untested. The courts and judiciary have not always proved sympathetic to ombudsmen (Ackner 1993) and if cases come before them the courts may seek to impose more formal procedures, as the court's procedure normally requires. Given the emphasis placed on speed and minimum formality by the TIO and private sector ombudsmen more generally, the intervention of the Court into their decision making processes is likely to damage the confidence and trust that the users have in the decision-making processes of private sector ombudsmen (Financial Ombudsman Service 2000). Indeed, consumers may decide to go directly to Court on issues that have a legal basis.

Moreover, the desire to resolve disputes quickly has led to the prominence of early resolutions. Private ombudsman institutions have invested considerable resources in the initial contact stage and place great emphasis on "taking the earliest opportunity to resolve an incipient complaint and nip it in the bud" (Merricks 2001). This speedy dispute resolution may entail, for example, helping someone formulate their initial complaint to the service provider concerned after directly approaching the TIO, or using mediation or conciliation techniques rather than embarking on a full investigation (Financial Ombudsman Service 2002). Currently, the TIO have set particular key performance indicators (KPIs) in accordance with standard industry practice to measure the period of time it takes to resolve matters. For instance, both the Communications Ombudsman Services and the Communications and Internet Services Adjudication Scheme (CISAS) in the UK have identified early resolution as the most critical data set of the KPI's. The Communications Ombudsman Services published in its 2015 annual report that all individual complaints were resolved within eight weeks and that 97 per cent of complaints were resolved within six weeks (TIO 2015g). Additionally, in its quarterly reports CISAS indicated that 94.1 per cent 
of all received cases were resolved within 6 weeks, in the second Quarter of 2015 (CISAS 2015).

The impact of this approach on the TIO's operation can be clearly seen from figures disclosed in the TIO's 2014-15 annual report. Indeed, 90 per cent of consumer contacts were dealt with within one business day, whilst the other 10 per cent included a total of 12,083 cases requiring conciliations and/or investigations, in which the TIO closed 80 per cent of conciliated complaints within 30 business days and 80 per cent of investigated complaints within 70 business days. Only five per cent of open complaints were unresolved for more than 120 days out of a total of 124,417 complaints in the year ending July 2015 (TIO 2015g).

So, what is the problem with early resolution? While early resolution does not necessarily bring undesirable impacts on its own, there are strong arguments in support of alternative dispute resolution methods that require longer negotiation periods, such as mediation and conciliation (Morris \& James 2002). For instance, the TIO does not record outcomes of early resolutions achieved at the referral stage (TIO 2015g) which can possibly lead to either undiscovered serious one-off problems or serious systemic weaknesses. At the same time, it would not be advisable that the TIO place too much significance solely on mediation and conciliation as this may also alter the ultimate advantage of the TIO, which as an alternative to the Court, the TIO is able to visualise the broader picture and identify broad problems as opposed to only resolving individual cases. Therefore, industry specific ombudsmen like the TIO should have mechanisms in place to monitor what happens to complainants sent back to service providers at the referral stage in order to check whether conciliation is tending to operate in favor of one party; to consider whether there is potential for serious one-off problems, or indeed, serious systemic weaknesses "hidden" by the emphasis on informal processes. Here, the TIO must balance the priorities of their stakeholders by ensuring that individual complainants are provided with a speedy and fair resolution, that the TIO decision making processes are consistently monitored for bias and that the service providers are receiving informed recommendations to improve the quality of their services.

\section{The misleading use of "ombudsman" as a term for private sector ombudsmen}

Administrative law embodies the legal framework within which public administration is carried out. It derives from the need to create and develop a system of public administration under law, a concept that may be compared with the much older notion of justice under law. Since administration involves the exercise of power by the executive arm of government, administrative law is of constitutional and political, as well as juridical, importance. Although there is no universally accepted definition of administrative law, it may rationally 
be understood to cover the organisation, powers, duties, and functions of public authorities of all kinds engaged in administration, their relations with one another and with citizens and non-governmental bodies. Administrative law also constitutes legal methods of controlling public administration and the rights and liabilities of officials (Cane \& McDonald 2013).

Constitutional law complements administrative law to a large extent, and the line between them can be difficult to draw. While the legislature, the courts, and the administration are regarded as constitutional matters, the substantive and procedural provisions concerning the administration as well as judicial review of the administration are regarded matters of administrative law. However, some matters, such as the responsibility of ministers, cannot be exclusively assigned to either administrative or constitutional law. Elsewhere, some French and American jurists regard administrative law as including parts of constitutional law. The law relating to public health, education, housing, and other public services could logically be regarded as administrative law (Robson 2013; 1951). By the same token, public ombudsman institutions, scrutinising the work of the executive within public administration, should also be regarded as part of administrative law.

Private sector ombudsmen are different. A typical private sector ombudsman institution, such as the TIO, has its main function and additional functions. As established in the key claim above in this paper, the main function of a private sector ombudsman is to provide redress and remedies, which are comparable to the courts. The additional functions normally include empowering consumers, facilitating industry regulators to develop consumer policies and providing feedback to the service sector as a whole. The additional functions are the functions that no court can perform. Nonetheless, neither the main function nor the additional functions can be regarded as administrative in nature given the fact that these functions have little relevance to the public administration (or the executive) arm of the constitutional arrangement.

While it is easy to justify the constitutional standing of the public ombudsman in the administrative law system, it is nearly impossible to position the private sector ombudsman in the existing constitutional arrangement according to the established separation of powers principle. Due to the divergent responsibilities of the public and private ombudsmen alongside the legitimacy that the public ombudsman receives as part of the administrative law system, the use of 'ombudsman' in the private sector deceptively capitalises on the legality of the public ombudsman in order to generate a public perception of authority and a tenuous connection with the roles in which the public ombudsman has performed for decades. 
In fact, the use of the term "ombudsman" has already created much confusion in recent years. As the Australian Commonwealth Ombudsman, Professor McMillan, describes: “

... the proliferation of private sector complaints bodies have raised issues as to whether private bodies should be allowed to adopt the name "ombudsman" ... the problem has more to do with unconstrained and unsystematic use of the term; this was followed by an elaboration of the problem of public deception and public confusion.” (McMillan 2008).

The TIO, like many other private sector ombudsmen, does not differ from the description provided by Professor McMillan as it was set up and continually funded by the industry as a sectorial specific dispute resolution scheme. Therefore, it does not have any relevance to the contemporary understanding of administrative law and it is difficult to justify its use of the title "ombudsman".

The other important distinguishing feature of the TIO's practice from the very purpose of administrative law is its function regarding the balancing of powers. Public ombudsmen level the field by providing the complainant with an opportunity to cut through the red tape of government entities at no charge, whereas the situation in the telecommunications industry, where the TIO operates, can be very different. A Canadian Justice once stated, 'the Ombudsman can bring the lamp of scrutiny to otherwise dark places even over the resistance of those who would draw the blinds.' (Re Alberta Ombudsman Act 1970). So, who would draw the blinds? Parties in the position of being able to draw the blinds could include government officials in the public sector and large, powerful firms in the private sector.

The earlier telecommunications market comprised a small number of big firms and the TIO could effectively balance the bargaining power between the individual complainant and these big firms at that time. Although these big firms still remain as key players, the industry has already seen the growth of a number of smaller or small private firms as a result of introducing sectorial competition and deregulation. With the development of the current National Broadband Network (NBN) project, the industry is expected to welcome more small players into the retail telecommunications market and many of these small firms are expected to join the TIO scheme. With an increasing number of small firms joining in, the role of the TIO in balancing powers decreases as these small businesses may not be in the position of 'drawing the blinds'. Again, this is another reason to differentiate the private sectorial dispute resolution scheme, such as the TIO, from the public ombudsman. To address this trend, the TIO may need to revise its operational guide and fee structure by considering the position of its smaller members. 


\section{Conclusion}

Public sector ombudsmen still hold a strong standing in the current provision of administrative justice while private sector ombudsmen do not offer the same effect, as they are no longer complimenting the administration scheme, but rather the judicial system. Private ombudsman institutions justify their existence by offering service functions in forming a desirable relationship between the citizen, government, lawmakers and the industry. There are, however, fundamental issues, which might hinder the development of the ombudsman institution and also compromise the rights of the individuals in seeking justice.

This paper accepts that private sector ombudsmen can be an effective industry selfregulation scheme. This however does not mean that they should not be subject to authoritative and standardised quality control assurance mechanisms to ensure that both consumer complainants and the participating firms are getting an efficient and fair deal. Unfortunately, such a mechanism is not yet being considered in the telecommunications industry

By using the TIO as a typical private sector ombudsman institution, this paper establishes the nature of the TIO as a substitute to the judicial system on matters arising from the service sector it operates within. Proceeding from this claim, this paper examines five separate issues and argues that the TIO may go beyond providing legal rights in a more accessible forum and actually provide different rights and remedies from those available in the courts and tribunals. The very fact that the TIO can expand its scope of operation requires further justification and immediate attention from relevant stakeholders. In addition, this paper highlights a challenge for the TIO to balance the extent to which it tolerates discretionary power being exercised by its delegated decision-makers, and to ensure that general decision-making principles are appropriately applied across the entire institution. To respond to this challenge, so as to gain public confidence and industry support, setting up special courses to train the ombudsmen staff is essential and a good way to start, but there is a lot more that needs to be done in this regard.

Finally, while it is easy to justify the constitutional standing of the public sector ombudsman institution in the administrative law system, it is certainly more difficult to place the private ombudsman institution in the constitutional arrangement, according to the established separation of powers principle. Private sector ombudsman institutions do not seem to have relevance to the contemporary understanding of administrative law. On this point, this paper argues that the use of the word "ombudsman" in settling sectorial consumer disputes can be 
a misleading concept, which may generate a false public perception by linking it to the various roles of public administration carried out by public ombudsmen for decades.

\section{References}

Abraham, A. (2008). The Future in International Perspective: The Ombudsman as Agent of Rights, Justice and Democracy. Parliamentary Affairs, 681.

Ackner, L. (1993). Report on a New Unified Complaints Procedure for the Personal Investment Authority. Dispute Resolution Report.

Australian Administrative Law Policy Guide. (2015). Retrieved from Attorney General's Department, Australian Government:

https://www.ag.gov.au/LegalSystem/AdministrativeLaw/Documents/Australian\%20Admin istrative\%20Law\%20Policy\%20Guide.pdf

Australian Bureau of Statistics. (2015). Population clock. Retrieved from ABS: http://www.abs.gov.au/ausstats/abs@.nsf/o/1647509ef7e25faaca2568a900154b63?OpenD ocument

Australian Communications and Media Authority. (2015). Communications Report 2014 2015. ACMA.

Bames, J. (1993). Is Administrative Law the Corporate Future? Australian Business Law Review, 66.

Birds, J., \& Graham, C. (1988). Complaints Mechanisms in the Financial Services Industry. Civil Justice Quarterly, 317.

Cane, P., \& McDonald, L. (2013). Principles of Administrative Law. Oxford University Press. CISAS. (2015). CISAS KPI Report for the second Quarter of 2015. Retrieved from http://www.cedr.com/docslib/CISAS KPI Report for the second Quarter of 2015.pdf

Coase, R. (1960). The Problem of Social Cost. Journal of Law and Economics, 1-44.

Commonwealth Ombudsman. (2015a). About Commonwealth Ombudsman. Retrieved from Commonwealth Ombudsman: http://www.ombudsman.gov.au/about/our-history

Commonwealth Ombudsman. (2015b). Complaints the Ombudsman can investigate.

Retrieved from Commonwealth Ombudsman:

http://www.ombudsman.gov.au/pages/making-a-complaint/complaints-the-ombudsmancan-investigate/

Financial Ombudsman Service. (2000). Laying the Foundations: First Annual Report. 
Financial Ombudsman Service. (2002). Annual Review and Report \& Financial Statements. Flohr et al. (2010). Wolfsberg principles against money-laundering in banks. Hoffman.

Gill, C. (2014). The evolving role of the ombudsman: a conceptual and constitutional analysis of the "Scottish solution" to administrative justice. Public Law, 662.

Gilling, B. (1998). The Ombudsman in New Zealand. Palmerston North: Dunmore Press.

Gunningham, N., \& Rees, J. (1997). Industry Self-Regulation: An Institutional Perspective. Law and Policy, 363.

Hilson, C. (2002). Judicial Review, Policies and the Fettering of Discretion. Public Law, 111.

Kagan, B. (1982). Going By The Book: The Problem of Regulatory Unreasonableness. Philadelphia: Temple University Press.

Kirkham, R., Thompson, B., \& Buck, T. (2009). Putting the Ombudsman into Constitutional Context. Parliamentary Affairs, 602.

McMillan, J. (2008). What's in a name? Use of the term "Ombudsman". Australian and New Zealand Ombudsman Association Conference.

Merricks, W. (2001). Lessons from Merging the Financial Ombudsman Schemes. British and Irish Ombudsman Association Conference. London.

Morris, P. (1987). The Banking Ombudsman. Journal of Banking Law, 131.

Morris, P., \& Hamilton, J. (1996). The Insurance Ombudsman and PIA Ombudsman: A Critical Comparison. North Ireland Legal Quarterly, 119.

Morris, P., \& James, R. (2002). The Financial Ombudsman Service - A brave new world in 'ombudsmanry'. Public Law, 640.

Nobles, R. (2001). Keeping ombudsmen in their place - the courts and the Pensions Ombudsman. Public Law, 308.

NSW Local Court Act. (2007). Section 29.

Paunio, R. (2009). The Ombudsman as Human Rights Defender. The 9th World Conference of the International Ombudsman Institute. Stockholm.

Re Alberta Ombudsman Act, 10 (1970). doi:Re Alberta Ombudsman Act (1970), 10 D.L.R. (3d) 47, per Milvain C.J.T.D.

Reif, L. (2004). The Ombudsman, Good Governance and the International Human Rights System. Leiden: Martinus Nijhoff Publishers. 
Robson, W. (1951). Justice and administrative law: a study of the British Constitution. Greenwood Press.

Robson, W. (2013). Administrative law: Judicial review of administration. Retrieved from E Page and Encyclopaedia Britannica.

Sammeck, J. (2012). A new institutional economics perspective on industry self-regulation. Springer.

Seneviratne, M. (1994). Ombudsmen in the Public Sector. Open University Press.

Seneviratne, M. (2002). Ombudsmen: Public Services and Administrative Justice. Cambridge : Cambridge University Press.

Smith, S., \& Wood, J. (2009). Industry Ombudsman Schemes Twenty Years On: World benchmark or industry captured? Alternative Law Journal, 3 .

Telecommunications Industry Ombudsman. (2012). Systemic Issues. Retrieved from TIO: http://ar2012.tio.com.au/performance/systemic-issues

Telecommunications Industry Ombudsman. (2014a). Annual Report. Retrieved from TIO: https://www.tio.com.au/ data/assets/pdf file/0005/162662/TIO-2014-Annual-Report-

WEB.pdf

Telecommunications Industry Ombudsman. (2014b). Complaints we handle. Retrieved from TIO: https://www.tio.com.au/about-us/terms-of-reference-and-company-constitution/2.complaints-we-handle

Telecommunications Industry Ombudsman. (2015a). Benchmarks for Industry-Based Customer Dispute Resolution Schemes. Retrieved from TIO:

https://www.tio.com.au/ data/assets/pdf file/0004/131764/Benchmarks DIST1997.pdf

Telecommunications Industry Ombudsman. (2015b). career. Retrieved from

Telecommunications Industry Ombudsman:

https://www.tio.com.au/ data/assets/pdf file/o019/155017/PD-Enquiry-Officer-May2014.pdf

Telecommunications Industry Ombudsman. (2015c). Complaint outcomes. Retrieved from Telecommunications Industry Ombudsman: http://annualreport.tio.com.au/complainttrends/outcomes

Telecommunications Industry Ombudsman. (2015d). Evidence and Decision Making - 7.o Fair and Reasonable. Retrieved from: http://www.tio.com.au/about-us/policies-andprocedures/evidence-and-decision-making\#70FairandReasonable 
Telecommunications Industry Ombudsman. (2015e). Funding. Retrieved from TIO: https://www.tio.com.au/about-us/funding

Telecommunications Industry Ombudsman. (2015f). Objectives and Principles. Retrieved from TIO: https://www.tio.com.au/about-us/policies-and-procedures/objectives-andprinciples

Telecommunications Industry Ombudsman. (2015g). TIO annual report . Melbourne: Telecommunications Industry Ombudsman.

Telecommunications Industry Ombudsman. (2015h). TIO complaints: the year in review 2013 - 2014 Complaints Report. Retrieved from TIO:

https://www.tio.com.au/ data/assets/pdf file/0006/158964/TIO-complaints-the-yearin-review-2013-14 WEB.pdf

Telecommunications Industry Ombudsman. (2015i). About Us. Reterieved from TIO: https://www.tio.com.au/about-us

Telecommunications Industry Ombudsman. (2015j). 2014-2015 Snapshot. Retrieved from TIO: http://annualreport.tio.com.au/performance/2014-15-snapshot

Tyldesley, P. J. (2003). The Insurance Ombudsman Bureau - the early history. Journal of Insurance, 34 .

Widdowson, L., \& Li, G. (2013). Telecommunications industry self-regulation: assessing the Telecommunications Industry Ombudsman Scheme in Australia. International Journal of Private Law, 315.

Wyatt, J. (1961). The Citizen and the Administration: The Redress of Grievances. London: Stevens. 